\title{
Free Fatty Acids, Central Nervous System and Bromazepam
}

\author{
By C. Papageorgiou, G. Levis, I. Kondou and S. Moulopoulos
}

Department of Clinical Therapeutic' (Head: Prof. S. D. Moulopoulos), Athens University, "Alexandra" Hospital. Athens.

(Received December 17.1980/September 2.1981)

Summary: The concentrations of free fatty acids in plasma were estimated in thirty-three subjects, before and after ( 24 hours and 72 hours) the start of bromazepam oral administration in a daily dose of $6 \mathrm{mg}$ ( $1.5 \mathrm{mg}$ at 7 a.m., $1.5 \mathrm{mg}$ at 3 p.m. and $3 \mathrm{mg}$ at 11 p.m.). A fourth estimation was performed 72 hours after drug discontinuation. A control group of twelve subjects received a placebo according to the same dosage pattern.

In comparison with the first estimation, the subsequent free fatty acid values showed a significant decrease $(p<0.05 . p<0.05$ and $p<0.001$, respectively), whereas the control group showed no significant decrease $(\mathrm{p}>0.05)$.

The aim of the present article is to present the results of the three day-standard oral administration of bromazepam on free fatty acid concentration of plasma.

All the samples, including the control group, were taken from a population free from any disease affecting adipose tissue metabolism.

\section{Freie Fettsäuren, Zentralnervensystem und Bromazepam}

Zusammenfassung: Bei 33 Personen wurden die freien Fettsäuren im Plasma vor und nach Beginn ( $24 \mathrm{~h}$ und $72 \mathrm{~h}$ ) der oralen Verabreichung von $6 \mathrm{mg}$ Bromazepam pro die bestimmt. 72 Stunden nach dem Absetzen des Medikaments wurde die Konzentration der freien Fettsäuren erneut bestimmt. Diese Bestimmung nach demselben Schema erfolgte auch bei einer Kontrollgrupppe von 12 Probanden, die ein Placebo erhielten.

Im Vergleich zum Resultạt der ersten Bestimmung zeigen die nachfolgenden Werte eine signifikante Verminderung. Hingegen wurde bei der Kontrollgruppe keine Abnahme festgestellt.

Zweck dieser Arbeit war die Analyse der Einwirkung von Bromazepam auf die freien Fettsäuren im Plasma nach dreitägiger standardisierter oraler Verabreichung des Medikamentes. Die Probanden, sowohl die Patienten wie auch die Kontrollpersonen, wiesen keine Krankheit auf, die den Stoffwechsel des Fettgewebes beeinflußt.

\section{Introduction}

The influence of the central nervous system (CNS) on lipid metabolism and particularly, on free fatty acid mobilization is indisputable. Its exact mechanism. how: ever. remains to be clarified.

The concentration of free fatty acids in plasma is generally accepted as a sensitive measure of CNS arousal (1-6).

The purpose of the present study is to examine the possible influence of a known CNS-acting drug, the tranquillizer bromazepam, on the concentration of free fatty acids in human plasma. Such an influence would constitute indirect evidence of CNS regulation of the mobilization of free fatty acids in man, mainly through the hypothalamus and limbic system.

\section{Materials and Methods}

Patients

Thirty-three subjects, hospitalized for a clinical and laboratory investigation. were selected for the apparent absence of any' organic disease; this disease-free status ivas later confirmed. To minimisc any possible distress from the hospitalization itself. the subjects were studied between the 2nd and 3rd day after admission. All of them were in a 12 -hour state of fasting during the 
lour morning periods of observation. There was no tobacco. coffice or teal consumption. No subject was receiving medication, and all subjects were resting without exercise. The women, still in reprolluctive age, were studied between the 10th and 20 th day of their menstrual cycle.

The venipunctures were all performed by the same physician, when the patient wass still in bed, just after awakening, and the tourniquet applieation did not exceed 60 seconds. The administered tranquillizer was the benzodiazepine, bromazepam (Lexotan ${ }^{(}$〈Roche)), administered orally.

lour sanıples were taken from each subject. namely:

I. Belore drug administration.

II. 24 hours after the first administration of the drug $(6 \mathrm{mg} /$ $24 \mathrm{~h}$ in doses of $1.5 \mathrm{mg}$ at $7 \mathrm{a} . \mathrm{m} ., 1.5 \mathrm{mg}$ at $3 \mathrm{p} . \mathrm{m}$. and $3 \mathrm{mg}$ at 11 p.m.1.

III. 72 hours after the first administration of the drug, with the same dosage pattern as above.

IV. 72 hours after drug discontinuation.

It was not possible to complete the study for all subjects, becausc some of them left the hospital earlier than anticipated.

Another group of subjects (12 cases) was used as a control group. Thesc subjects, which were selected under the same conditions, were given placebo tablets according to the above dosage pattern.

\section{Method}

Blood was collected into an heparinized syringe at the various time intervals stated above, cooled at $4{ }^{\circ} \mathrm{C}$, and centrifuged for $10 \mathrm{~min}$ at $3000 \mathrm{~min}^{-1}$. The plasma was separated immediatcly after collection and deep frożen at $-20^{\circ} \mathrm{C}$ for later analysis.

Plasma free fatty acids were estimated in duplicate by the method of Ducombe using $0.2 \mathrm{ml}$ of plasma (7). For this purpose the reagent kit No 126055 of Boehringer Mannheim $\mathrm{GmbH}$ and palmitic acid standard ivere used. The quality of the assay was cstimated by measuring 10 replicate samples of two plasma pools $(0.16$ and $0.38 \mathrm{mmol} / \mathrm{l})$. In accordance with a previous report (8) the intraassay coefficient of variation was lower than $5.0 \%$. All samples of each patient were determined together in the same run immediately after the end of the test period. The results are given as the mean of duplicate samples. Statistical comparison between the four samples of each subject was made by the t-pair test.

\section{Results}

\section{Comparison between values I and II (tab. I)}

The free fatty acid concentrations in the first samples (before drug administration) ranged from $125 \mu \mathrm{mol} / \mathrm{l}$ to $815 \mu \mathrm{mol} / 1$ plasma (mean value $422 \pm 29.5 \mathrm{SEM} \mu \mathrm{mol} / \mathrm{l}$ ), i.e. within normal limits, except for five cases which were a little above the upper limit.

Values for the free fatty acid concentration of the second samples ( $24 \mathrm{~h}$ after beginning of drug administration) ranged from $110 \mu \mathrm{mol} / \mathrm{l}$ to $780 \mu \mathrm{mol} / \mathrm{l}$ plasma (mean value $363 \pm 25 \mathrm{SEM} \mu \mathrm{mol} / 1)$, i.e. within normal limits, only one case being slightly above the upper limit.

Values for the second samples were found to be significantly lower than those for the first samples $(p<0.05$ using the t-pair statistical analysis). In 24 out of 33 cases
Tab. 1. Free fatty acid concentration values ( $\mu \mathrm{mol} / 1$ plasma) of patients before (I) and $24 \mathrm{~h}$ after the first drug administration (II) and relative clianges ( 33 cases).

Frec fatty acids $(\mu \mathrm{mol} / 1)$

\begin{tabular}{|c|c|c|c|}
\hline Case & 1 & II* & Change $(\%)$ \\
\hline $\begin{array}{l}1 \\
2 \\
3 \\
4 \\
5 \\
6 \\
7 \\
8 \\
9 \\
10 \\
11 \\
12 \\
13 \\
14 \\
15 \\
16 \\
17 \\
18 \\
19 \\
20 \\
21 \\
22 \\
23 \\
24 \\
25 \\
26 \\
27 \\
28 \\
29 \\
30 \\
31 \\
32 \\
33\end{array}$ & $\begin{array}{l}330 \\
505 \\
470 \\
345 \\
300 \\
349 \\
230 \\
125 \\
225 \\
249 \\
136 \\
368 \\
475 \\
440 \\
567 \\
620 \\
815 \\
492 \\
510 \\
363 \\
614 \\
576 \\
581 \\
576 \\
400 \\
278 \\
317 \\
337 \\
671 \\
775 \\
378 \\
298 \\
238\end{array}$ & $\begin{array}{l}221 \\
441 \\
294 \\
218 \\
175 \\
297 \\
490 \\
110 \\
240 \\
122 \\
157 \\
357 \\
429 \\
455 \\
581 \\
468 \\
780 \\
439 \\
255 \\
504 \\
467 \\
423 \\
454 \\
527 \\
205 \\
256 \\
371 \\
329 \\
428 \\
580 \\
346 \\
334 \\
215\end{array}$ & $\begin{array}{rr}- & 33.6 \\
- & 12.7 \\
- & 37.4 \\
- & 36.8 \\
- & 58.3 \\
- & 14.9 \\
+ & 112.7 \\
- & 11.2 \\
+ & 6.6 \\
- & 51.0 \\
+ & 15.4 \\
- & 2.9 \\
- & 9.7 \\
+ & 3.4 \\
+ & 2.4 \\
- & 24.5 \\
- & 4.3 \\
- & 10.7 \\
- & 50.0 \\
+ & 38.8 \\
- & 23.9 \\
- & 26.6 \\
- & 21.9 \\
- & 8.5 \\
- & 48.8 \\
- & 8.0 \\
+ & 17.0 \\
+ & 15.1 \\
- & 36.2 \\
- & 20.0 \\
- & 8.5 \\
+ & 12.8 \\
- & 9.7\end{array}$ \\
\hline
\end{tabular}

$* p<0.05$ ( $t$-pair test statistical analysis of the $\mathrm{ll}$ versus the I estimation).

the values obtained were decreased from $2.9 \%$ to $58.3 \%$ with a mean value of $23.7 \pm 3.4$ SEM $\%$.

In three cases a small increase was noted (mean value: $4.13 \pm 1.27 \mathrm{SEM} \%)$. In four cases an increase was noted (mean value: $14.9 \pm 1.0$ SEM \%), whereas in two extreme cases rather large increases were noted $(38 \%$ and $112.7 \%)$.

\section{Comparison between values I and III (tab. 2)}

In 29 cases out of the initial 33, where a third sample was available ( 72 hours after initiation of drug admini:stration), the free fatty acid concentrations were also within normal limits, ranging between $98 \mu \mathrm{mol} / 1$ and $808 \mu \mathrm{mol} / \mathrm{l}$ plasma (mean value: $353 \pm 31 \mathrm{SEM} \mu \mathrm{mol} / \mathrm{l}$ ). Three cases were a little higher. In all 29 cases the free fatty acid concentrations in the plasma were significantly lower $(\mathrm{p}<0.05)$ in III than in I, using the t-pair test.

In 20 cases the observed decrease ranged from $9.1 \%$ to $67.1 \%$ (mean value: $27.8 \pm 2.8 \mathrm{SEM} \%$ ), in four cases 
lab. 2. Free fatty acid concentration values ( $\mu \mathrm{mol} / / \mathrm{plasma}$ ) of patients before (1) and $72 \mathrm{~h}$ after the first drug administration (III) and relative changes ( 25 cases).

\begin{tabular}{|c|c|c|c|}
\hline \multirow[b]{2}{*}{ Case } & \multicolumn{2}{|c|}{ Frec fatty acids $(\mu \mathrm{n} 10 \mathrm{l} / \mathrm{l})$} & \multirow[b]{2}{*}{ Change $(\%)$} \\
\hline & 1 & $111^{*}$ & \\
\hline 2 & 5115 & 352 & -30.3 \\
\hline 3 & 4711 & 199 & -57.6 \\
\hline 4 & 345 & 337 & $-\quad 2.3$ \\
\hline 5 & 300 & 280 & $-\quad 6.6$ \\
\hline 6 & 349 & 206 & -40.9 \\
\hline 10 & 249 & 1.37 & -44.9 \\
\hline 11 & 136 & 111 & -15.4 \\
\hline 12 & $36 K$ & 199 & -45.9 \\
\hline 14 & $4+0$ & 440 & 0 \\
\hline 15 & 567 & 577 & +1.7 \\
\hline 16 & $62(1)$ & 496 & -20.0 \\
\hline 17 & 815 & 446 & -45.2 \\
\hline 20 & 363 & 318 & -12.4 \\
\hline 22 & 576 & 434 & -24.6 \\
\hline 23 & 581 & 368 & -36.6 \\
\hline 24 & 576 & 467 & -18.3 \\
\hline 25 & 400 & 338 & -15.5 \\
\hline 26 & 278 & 216 & -22.3 \\
\hline 27 & 317 & 243 & -23.3 \\
\hline $2 x$ & 337 & 286 & -15.1 \\
\hline 29 & 671 & 277 & -58.7 \\
\hline 30 & 775 & 786 & $\begin{array}{l}-\quad 0.9 \\
0\end{array}$ \\
\hline 31 & 378 & 326 & -13.7 \\
\hline 32 & 298 & 344 & +15.4 \\
\hline 33 & 238 & 252 & +5.9 \\
\hline
\end{tabular}

* $\mathrm{p}<0.05$ (1-pair test statistical analysis of the III versus (he I estimation)
Tab. 3. Free fatty acid concentration values ( $\mu \mathrm{mol} / 1$ plasma) of patiunts before (l) and $72 \mathrm{~h}$ after drug discontinuation (IV) and relative changes (29 cases).

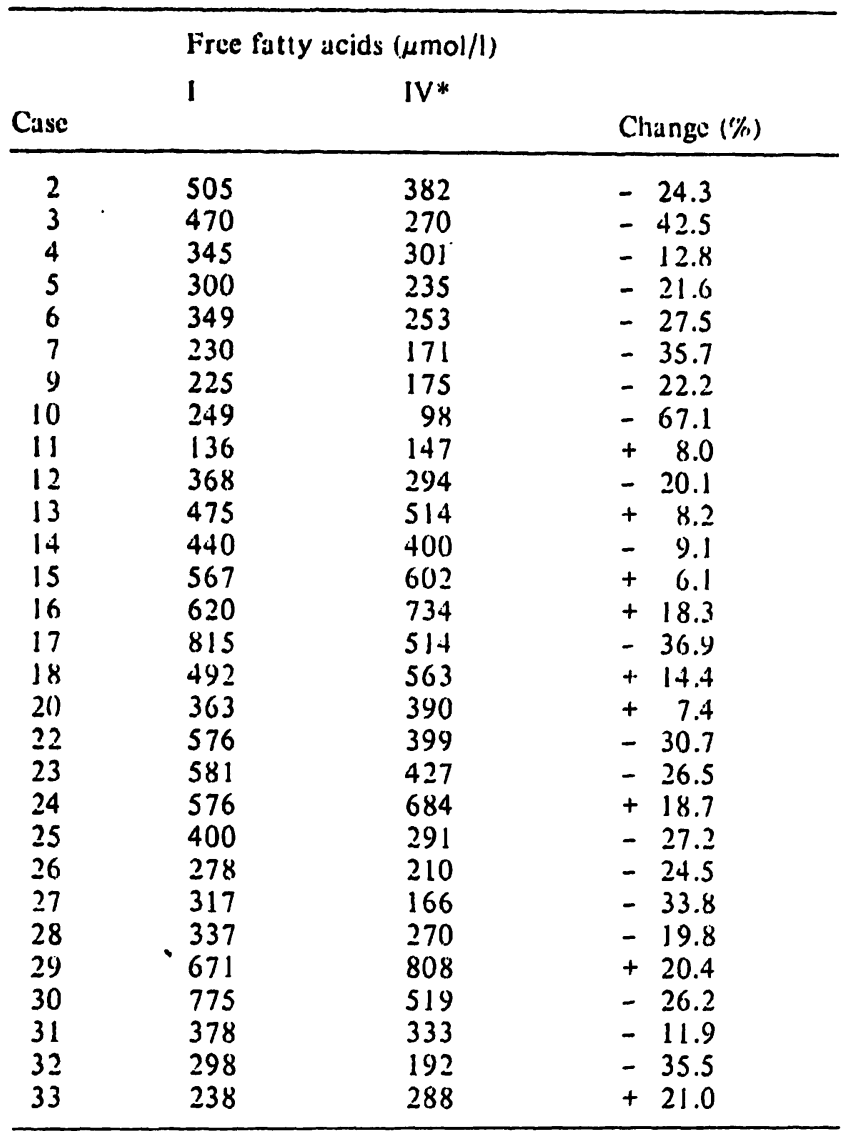

$* p<0.001$ (t-pair statistical analysis of the IV versus the ( estimation).

212 to $774 \mu \mathrm{mol} / \mathrm{l}$ (mean: $414 \pm 65 \mathrm{SEM} \mu \mathrm{mol} / \mathrm{l}$ ) for the I, II, III and IV measurements, respectively.

The observed changes between the I and the II. III and IV measurements were revealed by the use of the t-pair test ( $p>0.05, p>0.05, p>0.05$, respectively).

Analytically, on 9 out of the 12 members of the control group, the free fatty acid concentrations showed a percentage increase between the first and the second estimation ranging from $5.5 \%$ to $77.2 \%$ (mean value: $36.9 \pm 9.4$ SEM $\%$ ) while in the remaining 3 cases the values were decreased by $9.7 \%$ to $39.7 \%$ (mean value: $22.4 \pm 8.9 \mathrm{SEM} \%$ ).

In 9 out of the 12 cases the values between the first and the third measurement were increased $(5.8 \%$ to $91.1 \%$. mean value: $44.6 \pm 9.4 \mathrm{SEM} \%$ ) and in 3 cases decreased $(4.9 \%$ to $20.4 \%$, mean value: $13.2 \pm 4.5 \mathrm{SEM} \%)$.

In 10 out of the 12 members in the same control group the values obtained between the first and the fourth estimation were increased $(4.2 \%$ to $91.3 \%$. mean value: $45.8 \pm 9.3$ SEM \%) and in 2 cases decreased ( 7.2 to $43.8 \%$, mean value $25.5 \pm 18.2$ SEM $\%$ ). 


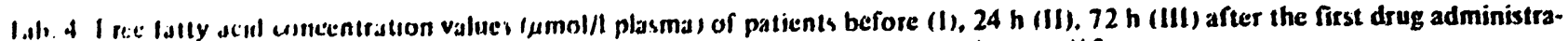
IIIn ard 7211 , diler druge diserenturuation (IV) and relative changes in control group (12 cases).

\begin{tabular}{|c|c|c|c|c|c|c|c|c|c|}
\hline \multirow[b]{2}{*}{ (a) } & \multicolumn{3}{|c|}{ I. ree lally acids (umol/l) } & \multicolumn{3}{|c|}{ l'rec fally actds $(\mu \mathrm{mol} / \mathrm{l})$} & \multicolumn{3}{|c|}{ Frec fatty acids $(\mu \mathrm{mol} / 1)$} \\
\hline & 1 & $11^{\bullet}$ & $\begin{array}{l}\text { ('hange } \\
\text { ('i) }\end{array}$ & 1 & $111 * *$ & $\begin{array}{l}\text { Cliunge } \\
(\%)\end{array}$ & 1 & IV*** & $\begin{array}{l}\text { Change } \\
(\%)\end{array}$ \\
\hline $\begin{array}{l}1 \\
3 \\
3 \\
4 \\
5 \\
6 \\
7 \\
4 \\
11 \\
10 \\
11 \\
12\end{array}$ & $\begin{array}{l}331 \\
241 \\
442 \\
378 \\
282 \\
2111 \\
472 \\
4(14 \\
272 \\
256 \\
226 \\
250\end{array}$ & $\begin{array}{l}211 \\
325 \\
521 \\
341 \\
369 \\
333 \\
529 \\
691 \\
287 \\
210 \\
259 \\
459\end{array}$ & $\begin{array}{r}-39.7 \\
+34.7 \\
+17.8 \\
-9.7 \\
+31.7 \\
+67.0 \\
+12.0 \\
+72.8 \\
+5.5 \\
+17.9 \\
+14.5 \\
+72.2\end{array}$ & $\begin{array}{l}351 \\
241 \\
442 \\
378 \\
282 \\
201 \\
472 \\
404 \\
272 \\
256 \\
226 \\
259\end{array}$ & $\begin{array}{l}279 \\
415 \\
468 \\
406 \\
369 \\
302 \\
404 \\
635 \\
352 \\
392 \\
432 \\
351\end{array}$ & $\begin{array}{r}-20.4 \\
+72.0 \\
+\quad 5.8 \\
+7.3 \\
-41.9 \\
+50.1 \\
-14.3 \\
+57.0 \\
+29.4 \\
+53.1 \\
+91.1 \\
+35.5\end{array}$ & $\begin{array}{l}351 \\
241 \\
442 \\
378 \\
282 \\
201 \\
472 \\
404 \\
272 \\
256 \\
226 \\
259 \\
\end{array}$ & $\begin{array}{l}393 \\
370 \\
410 \\
212 \\
322 \\
268 \\
706 \\
774 \\
410 \\
434 \\
398 \\
270\end{array}$ & $\begin{array}{l}+11.9 \\
+53.4 \\
-7.2 \\
-43.8 \\
+14.1 \\
+33.2 \\
+49.3 \\
+91.3 \\
+50.7 \\
+75.4 \\
+76.1 \\
+4.2\end{array}$ \\
\hline
\end{tabular}

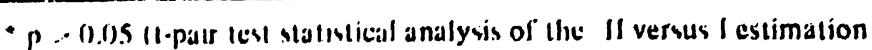

* p - (1.)5 (1.palr tes stalustical analyais of the III versus I estimation

*** p. (0).(15 Il-paur lest statistical allalysis of the IV versus I estimation).

All cascs under drug administration were classified according (1) the fluctuations of the values obtained, as follows:

Ciroup A: This includes 18 cases, where all the values obtained after drug administration were always lower (fig. I) than the first onc.

(jroup 13: 7 cases where the observed values were increased in estimation II and then decreased (fig. 2). In 5 cases the decrease was in estimation III, and in 2 cuses in estimation IV. In other words, the frec fatty acid values of this group.also eventually show a decrease.

Group ( : This comprises 6 cases where the decrease in estimation II is followed by an increase in estimation III (fig. 3).

In 3 of them there is a decrease in estimalion IV with respecl lo estimation I. In 2 of them there was no IV estimation. and in only onc case all the values remained at slightly $(5.9 \%)$ higher levels.

Group D: This includes only I case (fig. 4) where II and III wore decreased. followed by a slightly in. creased $(1.2 \%)$ IV.

Group L: The only included case (fig. 5) gave slightly increased values in all estimations $(2.4 \%, 6.1 \%$ and $1.7 \%$, respectively).

Briefly, in 18 oul of 33 cases the concentration of free fatty acids in plasma were decreased in all estimations, under drug influence. In 14 out of the remaining 15 cases there was a decrease in one or two estimations. and in one case only all the values were a little increased with respect to estimation I.
In contrast, there is no statistical correlation ( $p>0.05$ ) between the obtained values in the control group, after placeho administration (fig. 6).

\section{Discussion}

The results obtained, in all but one case, show a statistically significant decrease ( $p<0.05$ to $p<0.001$ ) of the concentrations of free fatty acids in plasma. with respect to those before treatment.

The above-mentioned decrease in concentrations of free fatty acids in plasma has the characteristic of being observed after $24 \mathrm{~h}$ administration and persists after the 72 hours of administration $(p<0.05)$ as well as 72 hours after bromazepam discontinuation $(p<0.001)$. A lot of research work, during the last years, refers to the CNS influence on the mobilization of free fatty acids $(1-5,9)$. The exact mechanism of such an influence is still unsettled, since the clinical studies as well as the experimental oncs have lead to various hypotheses as to the direct or indirect influence of the CNS on lipid metabolism. It has been shown that electrical stimulation of the hypothalamus causes a prompt elevation of the concentration of free fatty acids in plasma (10). Sapira et al. (11) found significant elevation in plasma free fatty acids, after psychological stimulation in volunteers. It is of intcrest to emphasize the gradual diminution of this reaction after the adaptation to the stimulus (12). Similar studies, clinical or experimental, show that any CNS stimulation, physical $(9,10,13)$ or psychological $(1,4,14)$, results in plasma free fatty acid eleva. tion. 

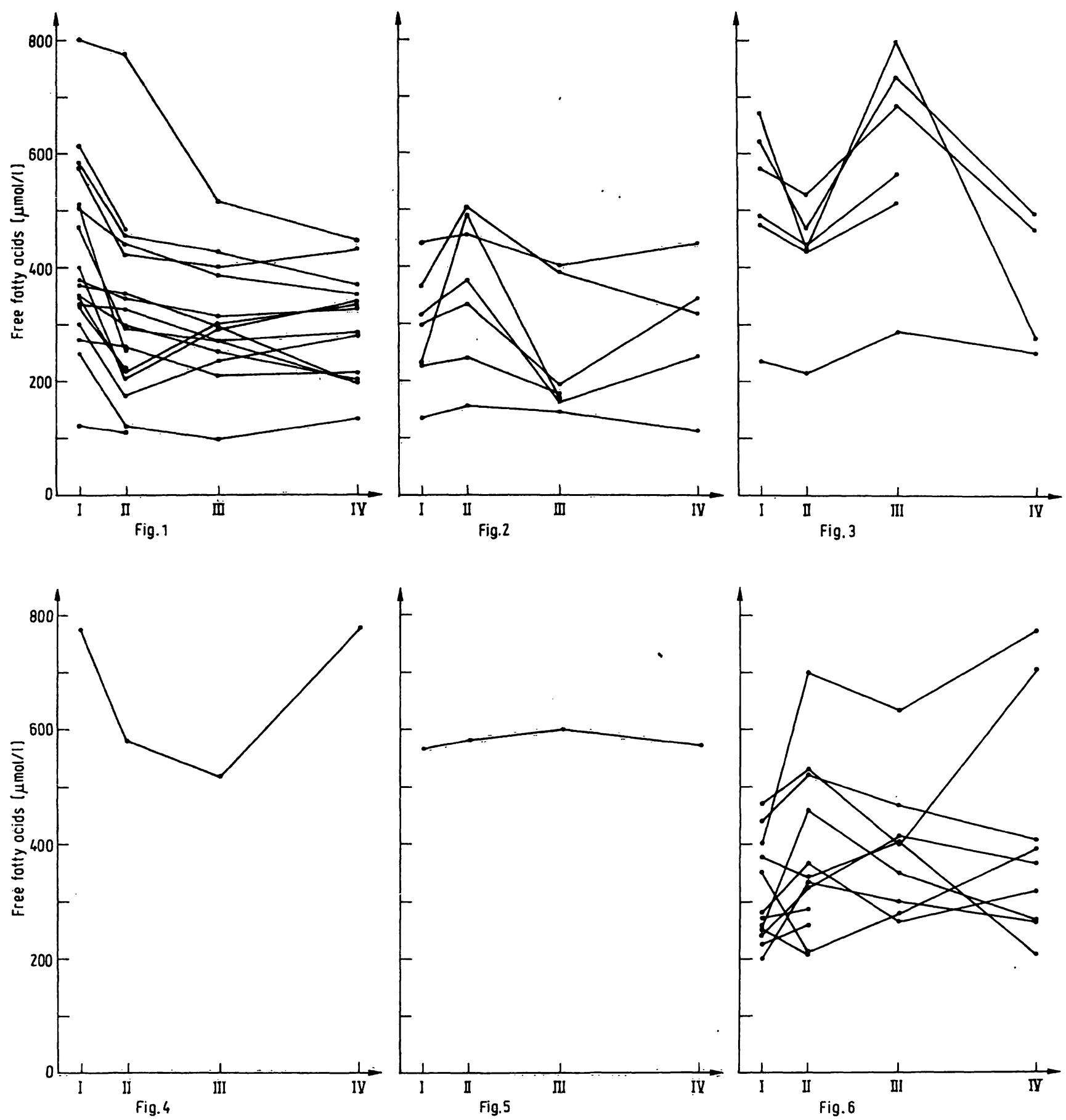

Fig. 1-6. Classification of all cases according to the fluctuations of the obtained free fatty acid concentration values.
$1=$ Before drug administration
II $=24 \mathrm{~h}$ after first drug administration
III $=72 \mathrm{~h}$ after first drug administration
$\mathrm{IV}=72 \mathrm{~h}$ after drug discontinuation.

On the other hand, peripheral blockade of the sympathetic "autonomic" nervous system by means of adrenergic or ganglionic blocking agents, inhibits the physiologic response of increased free fatty acids after threatening stimuli $(5,15-18)$. Experimental studies on animals prove the necessity of the peripheral nerve integrity in order to maintain an equilibrium in lipid metabolism (19).
This is probably due to the function of the autonomic routes of the nerve. Therefore, in case of nerve section, transmission of efferent autonomic impulses, chiefly from the hypothalamus, is interrupted.

It is generally accepted that the action of the nervous system upon free fatty acids is exerted by means of a complicated humoral mechanism (20). This includes 
a considcrable number of hormones and peptides, which contribute in maintaining a complex dynamic equilibrium, by either enhancing or inhibiting each other in various proportions (21). The substances known to be active in lipid mobilization, from adipose tissue, include adrenal steroids, glucagon, somatostatin, endorphins and enkephalins (22) and the hypophyseal hormones vasopressin, thyrotropin, corticotropin, prolactin, somatotropin and the $\beta$ - and $\gamma$-lipotropins (20), but the most important hormones regulating lipolysis are the neural and circulating catecholamines. The increase of catecholamines results in the elevation of the concentration of free fatty acids in plasma. The main pathway of catecholamine action on lipolysis is believed to be through the activation of adenylate cyclase, leading to an increased level of cAMP, which leads to phosphorylation and activation of triglyceride lipase. It seems likely that other pathways of catecholamine lipolysis, non cAMP-dependent, may also exist but their exact action remains unclear as yet (23). On the other hand, it is well-known that the catecholamine plasma concentration is elevated during the state of "stress" which rèsults form the arousal of CNS (17).

Thus the concentration of free fatty acids in plasma expresses one of the biochemical parameters of "stress".

Many investigators $(9,24-27)$ have worked on the response of free fatty acid concentrations in plasma to the administration of tranquillizers acting on the CNS. These studies were either performed on experimental animals or the tranquillizer was administered after induced hyperlipidaemia (26) or experimental neural stimulation. In these studies the estimation of free fatty acids was performed only after a single dose of the drug under investigation. Thus a comparison of our results with those concerning other benzodiazepines is not possible, because in the present study the administration of the tranquillizer is constant and of a long duration, imitating the usual clinical administration. This kind of administration plus the pharmacokinetic properties of bromazepam (half-life time $21-24 \mathrm{~h}$, regular elimination due to the absence of other active metabolites) (28) limits the role of interindividual variations of plasma bromazepam concentrations. In addition, the timing of estimations of free fatty acid concentration in plasma, as already described, examines both the cumulative phase and the steady state of bromazepam plasma concentration. Throughout this "steady state" phase intrasubject fluctuations were limited to a large extent.

The presence of active bromazepam plasma concentrations during the drug administration was judged by the clinical appearance of the patients i.e. their behavioural arousal level. They were slightly somnolent, whereas before the first dose they were normally wake. Finally the opinion that benzodiazepines exert a direct action on the releasing rate of free fatty acids from adipose tissue is excluded by the results of in vitro studies (9). We consider that our findings are more relevant to the true action of the drug, because the significant decrease of free fatty acids was observed in individuals under normal conditions, without a previous deviation of their neural or metabolic functions. Furthermore, continuous drug administration represents a more constant action on the concentration of free fatty acids in plasma and is closer to the routine practice, where the tranquillizer is not administered in a single dose. In conclusion, our findings constitute one more indication that CNS inhibition causes a decisive control over lipid mobilization, reducing the concentration of free fatty acids in plasma.

\section{References}

1. Bogdonoff, M. D., Estes, E. H. \& Trout, D. L. (1959) Proc. Soc. Exp. Biol. Med. 100, 503-504.

2. Bogdonoff, M. D. (1960) Arch. Int. Med. 105, 505-509.

3. Bogdonoff, M. D., Estes, E. H., Jr., Harlan, W. R., Trout, D. L. \& Kirshner, N. (1960) J. Clin. Endocrinol. Metab. , 20,1333-1340.

4. Cardon, P. V. \& Gordon, R. S. (1959) J. Psychosom. Res. 4, 5-9.

5. Hamlin, J. T., Hickler, R. B. \& Hoskin, G. R. (1960) J. Clin. Invest. 39, 606-609.

6. Leites, S. M. \& Chou-Su (1963) Fed. Proc., Suppl. 22 T. $244-246$

7. Duncombe, W. G. (1964) Clin. Chim. Acta 9, 122-126.

8. Howorth. P. J. N., Gibbard. S. \& Marks, V. (1966) Clin. Chim. Acta 14,69-72.

9. Khan, A. U., Forney, R. B. \& Hughes, F. W. (1964) Arch. Int. Pharmacodyn. 151, 466-474.

10. Correll, J. W. (1963) Fed. Proc. 22, 574.

11. Sapira, J. D., Pittenger, R. A., Gerende, L. J., Small, J. \& Corul, M. (1965) Am. J. Med. Sci. 249, 428-431.

12. Stone, W. N., Gleser, G. C., Gottschalk, L. A. \& Jacono, J. (1969) Psychosom. Med. 31, 331-341.

13. Mallov, S. \& Witt, P. M. (1961) J. Pharmacol. 132, $126-130$

14. Carlson, L. A., Levi, L. \& Orö. D. (1968) J. Clin. Invest. 47, 1795-1805.

15. Bogdonoff, M. D., Weissler, A. M., Merritt, F. L., Harlan; W. R. \& Estes, E. H. (1959) J. Clin. Invest. 38, 989.

16. Bogdonoff, M. D., Weissler, A. M. \& Merritt, F. L. (1960) J. Clin. Invest. 39, 959-965.

17. Bogdonoff, M. D. \& Estes, E. H. (1961) Psychosom. Med. $23,23-3.2$

18. Havel, R. J. \& Golḍfien, A. (1959) J. Lipid Res. I, $102-108$.

19. Sidman, R. L. \& Fawcett, D. N. (1954) Anat. Rec. 118 , 487-492.

20. White, A., Handler, P., Smith, E., Hill, R. \& Lehman, R. I. (1978) Principles of Biochemistry. Sixth edition, p. 600. International Student edition. McGraw Hill, New York. 


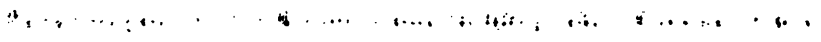
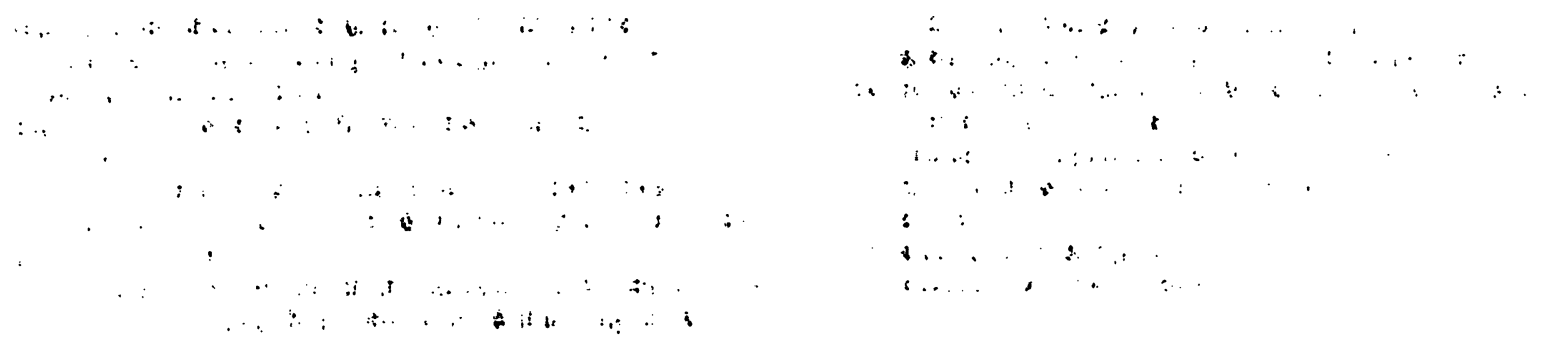

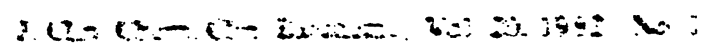

